\title{
MODELING AND OPTIMIZATION OF BAKERY YEAST (SACCHAROMYCES CEREVISIAE) VIABILITY BY USING EXPERIMENTAL DESIGN PROCEDURE
}

\author{
ANA-MARIA GEORGESCU ${ }^{1}$, DUMITRA RADUCANU ${ }^{1 *}$ \\ 1 "Vasile Alecsandri" University of Bacau, Calea Marasesti 157, Bacau, 600115, Romania
}

\begin{abstract}
This paper presents the application of $\mathrm{k}^{\mathrm{n}}$ experiment design procedure for simulation and optimization of growth capacity for baker's yeast, Saccharomyces cerevisiae. There were performed 27 experiments according to the experimental design procedure. The input variables were: the amount of carbohydrates $\left(\mathrm{X}_{1}\right)$, temperature $\left(\mathrm{X}_{2}\right)$ and $p \mathrm{H}\left(\mathrm{X}_{3}\right)$ and the output variable was the autolyzed cells $(\mathrm{Y})$. The optimal conditions for growth parameters of Saccharomyces cerevisiae were obtained for an amount of carbohydrates (glucose) of $46.8 \mathrm{~g} \cdot \mathrm{L}^{-1}$, a temperature of $30^{\circ} \mathrm{C}$ and a $p \mathrm{H}$ of 5.7.
\end{abstract}

Keywords: Saccharomyces cerevisiae, amount of glucose, autolyzed cells

\section{INTRODUCTION}

Researches on yeasts over recent years are of great interest, due to their potential in studying fundamental aspects of genetics, biotechnology, cell biology and the development of applicative fields of productive interest. Many yeast species have been used in the production of food: bread yeast (Saccharomyces cerevisiae), beer yeast (Saccharomyces pastorianus, Saccharomyces carlsbergensis), wine yeast (Saccharomyces uvarum). There are numerous studies that prove the use of yeasts in human nutrition or animal feed to compensate for protein deficiency, for industrial production of proteins, amino acids, water-soluble vitamins: vitamin B complex, vitamin $\mathrm{H}$ and vitamin $\mathrm{C}[1,2]$.

About $88 \%$ of the world's compressed yeast production, used in the bakery industry, and the rest for protein isolates, vitamins (group B) or enzymes (invertase, dehydrogenase, enzymes of the tympanic complex) that average yeast consumption in different countries being of $1.4 \div 2.5 \mathrm{~kg} /$ inhabitant and year [1, 3, 4].

Yeast is the term generally applied to an unicellular fungus, hundreds of species being now identified. One of the most notable and well-known species of yeast in health and wellness is known as Saccharomyces cerevisiae, belonging to the family Saccharomycetaae, phylum Ascomycota. This is also known by its more common names, brewer's yeast or baker's yeast [5-7].

Typically, brewer's yeast is used as a protein supplement, energy booster, immune enhancer or other vehicle, where other compounds can be inserted to create a commercialized health product $[1,3,8,9]$.

Bakery yeast is a cell biomass of Saccharomyces cerevisiae species (superior fermentation yeast), biomass made of living cells capable of producing the fermentation of dough sugars leading to the formation of ethyl alcohol and carbon dioxide, dough cloth and other secondary products, with role in bread formation.

\footnotetext{
* Corresponding author, email: dora.raducanu@ub.ro

(C) 2017 Alma Mater Publishing House
} 
The cultivation of Saccharomyces cerevisiae yeast in order to obtain biomass for the bakery industry is a complex of physico-chemical, biochemical, thermo-energetic and microbiological processes [1, 3, 4].

The quality and nature of the substrate, as well as physico-chemical parameters (temperature, $p \mathrm{H}$, humidity, chemical composition of the growth medium) influence the morphological and physiological characteristics of the yeast. The quality of yeast culture for physiological aspects is given by the ratio of autolyzed to active cells that should not exceed 5\% [9].

$p \mathrm{H}$ and temperature have a great influence on morphological characters, on multiplication capacity and viability of yeast cells. The type and amount of carbohydrates have a direct connection with metabolic processes of yeast $[1,3,10]$. Hence, these factors must be studied in depth, especially the interactions between them and their influence on yeast growth.

In this paper, the morphological aspects and growth capacity of bakery yeast under various experimental conditions were investigated. The varied parameters were the amount of glucose, temperature, $p \mathrm{H}$ and the response function was the autolyzed cells.

\section{EXPERIMENTAL}

\subsection{Materials and methods}

Dry active Pakmaya yeast from Rompak SRL provider was used. All chemicals were used without further purification and were supplied by Sigma Aldrich (peptone, glucose, agar), Arena Group S.A. (chloramphenicol) and S.C. Hipocrate 2000 SRL București (methylene blue).

The culture medium contained per liter (L): $10 \mathrm{~g}$ peptone, $40 \mathrm{~g}$ glucose, $15 \mathrm{~g}$ agar and $100 \mathrm{mg}$ chloramphenicol and a final $p \mathrm{H} \mathrm{5.6.} \mathrm{The} \mathrm{culture} \mathrm{medium} \mathrm{was} \mathrm{sterilized} \mathrm{at} 121^{\circ} \mathrm{C}$ for 15 minutes in Raypa autoclave, model no AES 28 and placed into Petri dishes. Each sample (Table 2) was seeded with $1 \mathrm{~mL}$ of yeast suspension $\left(10^{-1}\right)$ (three replicates). The autolyzed cells were identified with Thoma chamber, by using Euromex Holand optical microscope by coloration with $0.1 \%$ methylene blue $[4,9,10,11]$. Morphological aspects and the number of autolyzed cells were observed on the 20x objective microscope after $24 \mathrm{~h}$ of incubation.

\subsection{Factorial design}

In this paper, we investigat the influence of three parameters for the growth capacity of bakery yeast, which are expressed in terms of amount of glucose $\left(\mathrm{X}_{1}\right)$, temperature $\left(\mathrm{X}_{2}\right)$ and $p \mathrm{H}\left(\mathrm{X}_{3}\right)$ upon the response function, which was the autolyzed cells $(\mathrm{Y})$. The variation ranges are summarized in Table 1.

Table 1. Parameters that influence the growth capacity of bakery yeast.

\begin{tabular}{|l|c|c|c|c|c|}
\hline Parameters $\left(\mathrm{x}_{\mathrm{i}}\right)$ & $\begin{array}{c}\text { Reduced } \\
\text { variable }\end{array}$ & $\begin{array}{c}\text { Minimal } \\
\text { level } \\
\left(\mathrm{X}_{\mathrm{i}}^{\mathrm{min}}\right)\end{array}$ & $\begin{array}{c}\text { Median } \\
\text { level } \\
\left(\mathrm{X}_{\mathrm{i}}^{\mathrm{med}}\right)\end{array}$ & $\begin{array}{c}\text { Maximal } \\
\text { level } \\
\left(\mathrm{X}_{\mathrm{i}}^{\mathrm{max}}\right)\end{array}$ & $\Delta \mathrm{X}_{\mathrm{i}}$ \\
\hline Amount of glucose $\left[\mathrm{g} \cdot \mathrm{L}^{-1}\right]$ & $\mathrm{X}_{1}$ & 20 & 40 & 60 & 20 \\
\hline Temperature $\left[{ }^{\circ} \mathrm{C}\right]$ & $\mathrm{X}_{2}$ & 20 & 35 & 50 & 15 \\
\hline$p \mathrm{H}$ & $\mathrm{X}_{3}$ & 4.2 & 5.6 & 7 & 1.4 \\
\hline
\end{tabular}

\section{RESULTS AND DISCUSSION}

In Figure 1 is presented the image of observed yeast at microscope after $24 \mathrm{~h}$ of incubation. The autolyzed cells are colored in blue and the ratio between the autolyzed and the active cells below 5\% (Table 2) justifies a good metabolic state of yeast used in this research.

The autolyzed cells values of bakery yeast are presented in Table 2 . The reduced values of the varied growth parameters are presented in parenthesis. Three other tests were also realized in the central point of the domain $(0$, $0,0)$ to calculate the significance of the program; the obtained values are shown in Table 2. 


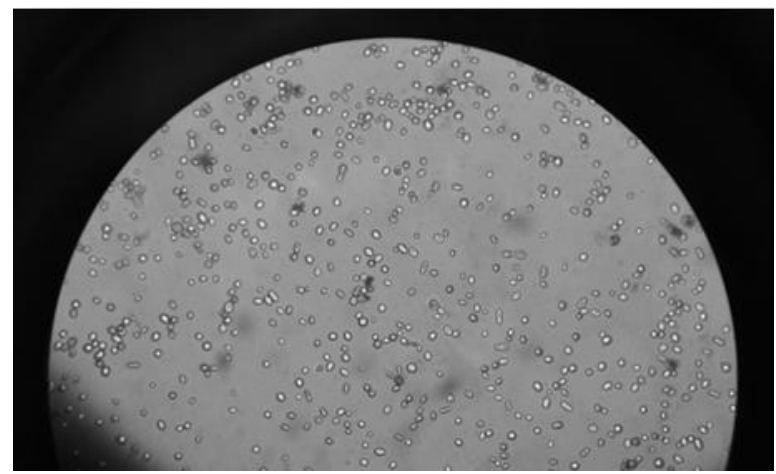

Fig. 1. Observed yeast at microscope (20x) after $24 \mathrm{~h}$ of incubation (P13).

Table 2. Varied parameters, response function for autolyzed cells of Saccharomyces cerevisiae and autolyzed / active cells ratio.

\begin{tabular}{|c|c|c|c|c|c|}
\hline Run & Amount of glucose, $\mathrm{g} / \mathrm{L}$ & Temperature, ${ }^{\circ} \mathrm{C}$ & $p \mathrm{H}$ & Autolyzed cells, $\%$ & $\begin{array}{c}\text { Autolyzed } \\
\text { /active cells } \\
\text { ratio, \% }\end{array}$ \\
\hline & $\mathrm{x}_{1}$ & $\mathrm{x}_{2}$ & $\mathrm{x}_{3}$ & $\mathrm{Y}$ & - \\
\hline 1 & $20(-1)$ & $20(-1)$ & $4.2(-1)$ & 41.9 & 0.72 \\
\hline 2 & $20(-1)$ & $20(-1)$ & $5.6(0)$ & 67.5 & 2.07 \\
\hline 3 & $20(-1)$ & $20(-1)$ & $7(+1)$ & 31.4 & 0.45 \\
\hline 4 & $20(-1)$ & $35(0)$ & $4.2(-1)$ & 25 & 0.33 \\
\hline 5 & $20(-1)$ & $35(0)$ & $5.6(0)$ & 73 & 2.70 \\
\hline 6 & $20(-1)$ & $35(0)$ & $7(+1)$ & 82.5 & 4.71 \\
\hline 7 & $20(-1)$ & $50(+1)$ & $4.2(-1)$ & 52 & 1.08 \\
\hline 8 & $20(-1)$ & $50(+1)$ & $5.6(0)$ & 76 & 3.16 \\
\hline 9 & $20(-1)$ & $50(+1)$ & $7(+1)$ & 4 & 0.04 \\
\hline 10 & $40(0)$ & $20(-1)$ & $4.2(-1)$ & 73 & 2.70 \\
\hline 11 & $40(0)$ & $20(-1)$ & $5.6(0)$ & 56 & 1.27 \\
\hline 12 & $40(0)$ & $20(-1)$ & $7(+1)$ & 18 & 0.21 \\
\hline 13 & $40(0)$ & $35(0)$ & $4.2(-1)$ & 59.2 & 1.45 \\
\hline 14 & $40(0)$ & $35(0)$ & $5.6(0)$ & $5.9(5.85 ; 6.5 ; 6)$ & 0.06 \\
\hline 15 & $40(0)$ & $35(0)$ & $7(+1)$ & 38 & 0.61 \\
\hline 16 & $40(0)$ & $50(+1)$ & $4.2(-1)$ & 38.5 & 0.62 \\
\hline 17 & $40(0)$ & $50(+1)$ & $5.6(0)$ & 33.33 & 0.49 \\
\hline 18 & $40(0)$ & $50(+1)$ & $7(+1)$ & 46 & 0.85 \\
\hline 19 & $60(+1)$ & $20(-1)$ & $4.2(-1)$ & 47 & 0.88 \\
\hline 20 & $60(+1)$ & $20(-1)$ & $5.6(0)$ & 52.2 & 1.09 \\
\hline 21 & $60(+1)$ & $20(-1)$ & $7(+1)$ & 23 & 0.29 \\
\hline 22 & $60(+1)$ & $35(0)$ & $4.2(-1)$ & 20 & 0.25 \\
\hline 23 & $60(+1)$ & $35(0)$ & $5.6(0)$ & 28 & 0.38 \\
\hline 24 & $60(+1)$ & $35(0)$ & $7(+1)$ & 7.3 & 0.07 \\
\hline 25 & $60(+1)$ & $50(+1)$ & $4.2(-1)$ & 38.5 & 0.62 \\
\hline 26 & $60(+1)$ & $50(+1)$ & $5.6(0)$ & 33 & 0.49 \\
\hline 27 & $60(+1)$ & $50(+1)$ & $7(+1)$ & 37.2 & 0.59 \\
\hline
\end{tabular}

The particular form of response function for factorial program of $3^{3}$ types is equation (1):

$$
\begin{aligned}
& Y=a_{o}+a_{1} \cdot x_{1}+a_{2} \cdot x_{2}+a_{3} \cdot x_{3}+a_{12} \cdot x_{1} \cdot x_{2}+a_{13} \cdot x_{1} \cdot x_{3}+a_{23} \cdot x_{2} \cdot x_{3}+a_{123} \cdot x_{1} \cdot x_{2} \cdot x_{3}+ \\
& +a_{11} \cdot x_{1}^{2}+a_{22} \cdot x_{2}^{2}+a_{33} \cdot x_{3}^{2}
\end{aligned}
$$

The polynomial coefficients, which were calculated according to the literature specifications [12-18]. The mathematical model which describes the response function of the optimization criteria is equation (2):

$$
\begin{aligned}
& Y=42.69-20.97 \cdot x_{1}-4.39 \cdot x_{2}-0.13 \cdot x_{3}+7.04 \cdot x_{1} \cdot x_{2}+6.39 \cdot x_{1} \cdot x_{3}+7.68 \cdot x_{2} \cdot x_{3}+ \\
& +14.15 \cdot x_{1} \cdot x_{2} \cdot x_{3}+4.46 \cdot x_{1}^{2}-3.92 \cdot x_{2}^{2}-3.06 \cdot x_{3}^{2}
\end{aligned}
$$

The $t$ - student test was used in order to determine the significance of the polynomial coefficients. First it is necessary to calculate the average value of the response function and the average value of the measurement 
errors according to the algorithm presented in the literature [12-18]. The $t$-student test results (Table 3 ) indicate that a1 and $\mathrm{a}_{123}$ terms have to be eliminated. The mathematical model of the function is equation (3):

$$
\begin{aligned}
& Y=42.69-20.97 \cdot x_{1}-4.39 \cdot x_{2}-0.13 \cdot x_{3}+7.04 \cdot x_{1} \cdot x_{2}+6.39 \cdot x_{1} \cdot x_{3}+7.68 \cdot x_{2} \cdot x_{3}+ \\
& +14.15 \cdot x_{1} \cdot x_{2} \cdot x_{3}+4.46 \cdot x_{1}^{2}-3.92 \cdot x_{2}^{2}-3.06 \cdot x_{3}^{2}
\end{aligned}
$$

Table 3. T-student test results.

\begin{tabular}{|c|c|}
\hline Coefficients & Coefficient value \\
\hline $\mathrm{t}_{0}$ & 656.88 \\
\hline $\mathrm{t}_{1}$ & 322.73 \\
\hline $\mathrm{t}_{2}$ & 67.60 \\
\hline $\mathrm{t}_{3}$ & 2.13 \\
\hline $\mathrm{t}_{12}$ & 108.33 \\
\hline $\mathrm{t}_{13}$ & 98.33 \\
\hline $\mathrm{t}_{23}$ & 118.20 \\
\hline $\mathrm{t}_{123}$ & 217.69 \\
\hline $\mathrm{t}_{11}$ & 68.71 \\
\hline $\mathrm{t}_{22}$ & 60.42 \\
\hline $\mathrm{t}_{33}$ & 47.09 \\
\hline
\end{tabular}

The effects simulation of the optimization study consists in discussing the absolute value and the sign of each coefficient separately. The $a_{o}$ value indicates that the optimal autolyzed cells percent is closed to $42.69 \%$.

The individual coefficients $\left(\mathrm{a}_{2}\right.$ and $\mathrm{a}_{3}$ ) are negative, so $\mathrm{x}_{2}$ and $\mathrm{x}_{3}$ variables have an unfavorable individual effect on yeast growth capacity. The interaction terms $\left(\mathrm{a}_{12}, \mathrm{a}_{13}, \mathrm{a}_{23}\right)$ being positive, it has a favorable action on yeast growth capacity.

Analyzing the quadratic term coefficient $\left(\mathrm{a}_{11}\right)$, which value is positive, it can be concluded that the response function is characterized by a minimum in relation to variable $\mathrm{x}_{1}$. Concerning the quadratic term coefficients $\left(\mathrm{a}_{22}\right.$ and $\mathrm{a}_{33}$ ) which values are negative, it can be said that the response function is characterized by a maximum in relation to variables $\mathrm{x}_{2}$ and $\mathrm{x}_{3}$.

For the response function obtained, the partial derivatives of first order were calculated, in rapport with each variable. By equating the partial derivatives of first order with 0 , the linear system resulted was resolved.

The optimal point searched was $(0.34 ;-0.35 ;-0.1)$, represented in dimensionless coordinates. It can be seen, that the optimal values for $\mathrm{x}_{1}, \mathrm{x}_{2}$ and $\mathrm{x}_{3}$ are within the limits of the domain $(-1,1)$ which initially were supposed.

The real values of the optimal conditions for autolyzed cells were obtained for an amount of glucose of $46.8 \mathrm{~g} \cdot \mathrm{L}^{-}$ ${ }^{1}$, a temperature of $29.75^{\circ} \mathrm{C}$ and a $p \mathrm{H}$ of 5.74 .

In this study, the autolyzed cells dependence was established according to three factors, amount of glucose, temperature and $p \mathrm{H}$, in order to establish the morphological aspects and growth capacity of yeast cells, dependence that can be illustrated using the curves presented in Figures 2-4.

In Figure 2 is presented the influence of temperature $\left(\mathrm{X}_{2}\right)$ and $p \mathrm{H}\left(\mathrm{X}_{3}\right)$ on autolyzed cells $(\mathrm{Y})$, when the amount of glucose $\left(\mathrm{X}_{1}\right)$ is constant. The negative signs of quadratic terms coefficients determine a maximum, so the response surface, which corresponds to the model is concave.

Figures 3 and 4 show a saddle-shape response surface determined by the different signs of quadratic terms coefficients. 


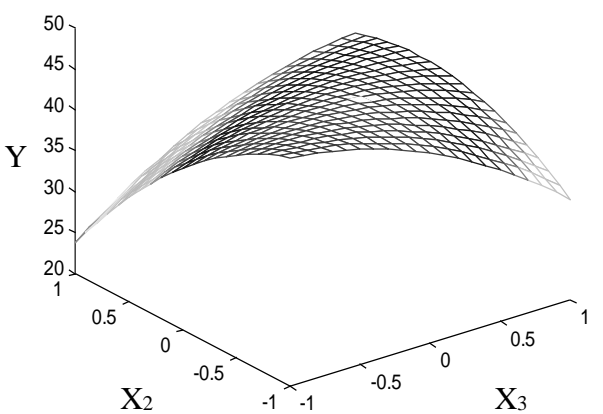

Fig. 2. Influence of temperature $\left(\mathrm{X}_{2}\right)$ and $p \mathrm{H}\left(\mathrm{X}_{3}\right)$ on autolyzed cells $(\mathrm{Y})$.

$Y=42.69-4.39 \cdot x_{2}-0.13 \cdot x_{3}+7.68 \cdot x_{2} \cdot x_{3}-3.92 \cdot x_{2}^{2}-3.06 \cdot x_{3}^{2}$

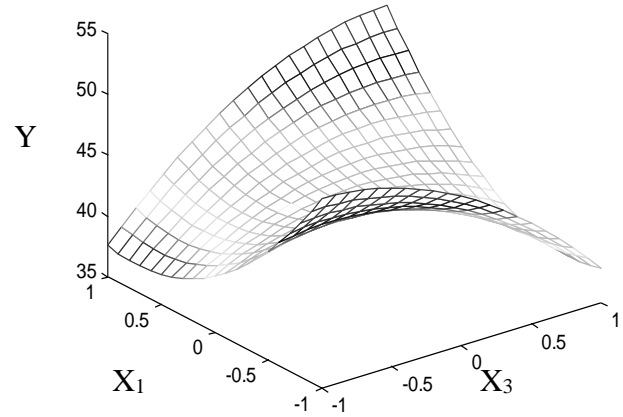

Fig. 3. Influence of amount of glucose $\left(\mathrm{X}_{1}\right)$ and $p \mathrm{H}\left(\mathrm{X}_{3}\right)$ on autolyzed cells $(\mathrm{Y})$.

$$
Y=42.69-0.13 \cdot x_{3}+6.39 \cdot x_{1} \cdot x_{3}+4.46 \cdot x_{1}^{2}-3.06 \cdot x_{3}^{2}
$$

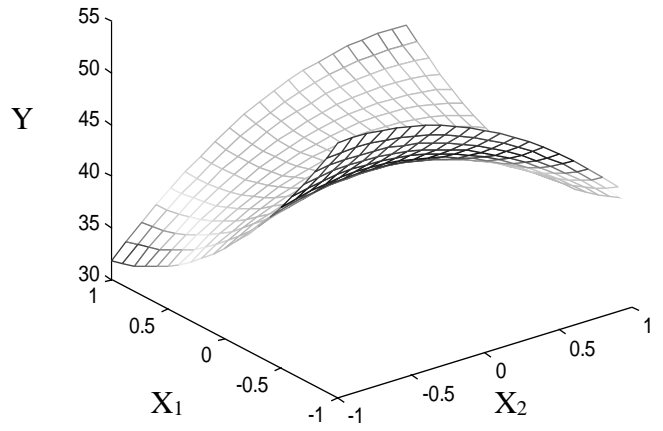

Fig. 4. Influence of amount of glucose $\left(\mathrm{X}_{1}\right)$ and temperature $\left(\mathrm{X}_{2}\right)$ on autolyzed cells $(\mathrm{Y})$.

$$
Y=42.69-4.39 \cdot x_{2}+7.04 \cdot x_{1} \cdot x_{2}+4.46 \cdot x_{1}^{2}-3.92 \cdot x_{2}^{2}
$$




\section{CONCLUSIONS}

The design experiments utilization in order to model and to optimize the bakery yeast growth capacity, demonstrate the viability of this analysis technique of experimental data. The factorial experimentation makes possible the estimation of decisive parameters effects of yeast growth capacity. Based on experimental data, an equation was elaborated by experimental programming, which is the expression of autolyzed cells of Saccharomyces cerevisiae, as a polynomial where the coefficients attached to the independent variables can be determined by regression analysis.

The optimal conditions for the growth parameters of Saccharomyces cerevisiae were obtained for an amount of glucose of $46.8 \mathrm{~g} \cdot \mathrm{L}^{-1}$, a temperature of $30^{\circ} \mathrm{C}$ and a $p \mathrm{H}$ of 5.7. The optimal value of autolyzed cells percent obtained by factorial planned experiments was $1.63 \%$.

The optimized values obtained from the experimental design are in agreement with the values of parameters initially explored. The value of autolyzed cells percent represents the optimal moment for cells morphology yeast (aspect and dimensions) and their degree of sprouting.

Based on the obtained results, researches will continue for increasing of yeasts potential to form biomass by optimizing the composition of culture media with regard to carbohydrates (monosaccharides, disaccharides). A good morphological and physiological quality have been verified in practice by an active / autolyzed cells ratio less than $5 \%$.

\section{REFERENCES}

[1] Dumitru, I.F., Vamanu, A., Popa, O., Drojdiile: biotehnologii clasice și moderne, Ed. Ars Docendi, București, 2002.

[2] Nicoara, C., Drojdiile - o sursă valoroasă de proteine și vitamine, Ed. Astra Blăjeană, anul XIV, vol. 1, no. 54, Blaj, 2010.

[3] Anghel, I., Vamanu, A., Popa, O., Biologia şi tehnologia drojdiilor, vol. III, Ed. Tehnica, Bucureşti, 1993.

[4] Dan, V., Microbiologia produselor alimentare. vol. 1. Morfofiziologia microorganismelor cu implicaţii în industria alimentară; Factori de control ai creşterii microbiene; Fermentatii, Ed. Alma, Galati, 1999.

[5] Moyad, M.A., Brewer's/baker's yeast (Saccharomyces cerevisiae) and preventive medicine: Part II., Urologic Nursing, vol. 27, no. 6, 2007, p. 560-561.

[6] Mortimer, R.K., Evolution and variation of the yeast (Saccharomyces) genome, Genome Research, vol. 10, 2000, p. 403-409.

[7] Marsit, S., Dequin, S., Diversity and adaptive evolution of Saccharomyces wine yeast: a review, FEMS Yeast Research, vol. 15, no. 7, 2015, p. 1-12.

[8] Eng, R.H., Drehmel, R., Smith, S.M., Goldstein, E.J., Saccharomyces cerevisiae infections in man, Sabouraudia, vol. 22, no. 5,1984, p. 403-407.

[9] Pintilie, C., Cercetari privind valorificarea drojdiilor de bere reziduale pentru obţinerea unor produse cu valoare nutriţională ridicata, Rezumat teza de doctorat, Cluj Napoca, 2011.

[10] Oprean, L., Researches concerning the preparation of plasmolysates from cells of the beer yeast Saccharomyces carlsbergensis, Studia Universitatea "Babeş-Bolyai", Biologie, Cluj-Napoca, XLVI, vol. 2, 2002, p. 99-103.

[11] Meyer, A., Deiana, J., Bernard, A., Cours de microbiologie générale: avec problèmes et exercices corigés, 2ème édition, Ed. Doin, 2004.

[12] Balaban, C., Jinescu, G., Experiment factorial pentru studiul unor procese şi procedee specifice ingineriei chimice, Revista de Chimie, vol. 35, no. 9, 1984, p. 845-850.

[13] Nistor, I.D., Jinescu, C., Azzouz, A., Elemente şi strategii în designul proceselor tehnologice, Ed. Alma Mater, Bacău, 2008.

[14] Nistor, I.D., Ursu, A.V., Georgescu, A.M., Ingineria proceselor biotehnologice şi alimentare. Aplicatii, Alma Mater Publishing House, Bacău, 2015.

[15] Lazic, Z., Design of experiments in chemical engineering, Wiley-VCH, Verlag GmbH and Co KGaA, New York, 2004.

[16] Georgescu, A.M., Brabie, G., Nistor, I.D., Penot, C., Nardou, F., Synthesis and characterization of Crpillared clays: modelling using factorial design methodology, Journal of Porous Materials, vol. 22, no. 4, 2015, p.1009-1019. 
[17] Georgescu, A.M., Brabie, G., Nardou, F., Nistor, I.D., Penot, C., Utilization of experimental design for specific surface area optimization of a pillared bentonite, Food and Environment Safety, 2013, vol. 12, no. 4, p. $284-290$.

[18] Jinescu, G., Ursu, A.V., Arus, V.A., Nistor, I.D., Miron, N.D., Modelisation et optimization de processus de coagulation de lait avec des argiles basiques par analyse factorielle, Studii şi cercetări ştiinţifice: Chimie şi Inginerie chimică, Biotehnologii, Industrie Alimentară, 2006, vol. 3, p. 713-719. 